\title{
Krop, topografiog kulturelle transformationer
}

\author{
Dansk håndbold som case
}

Inden for den såkaldt "topografiske vending" har man ofte haft fokus rettet mod rums og steders medialiserede udgaver. Ikke mindst den britiske og anglosaksiske turismeforskning har her leveret væsentlige bidrag til undersøgelser af rum og steders repræsentationer med vægten lagt på bl.a. dramatiserings- og narrationsformer. Blikket på, synet af og fremstillingen af rum og steder og de ledsagende mentale strukturer, stereotypier og forestillingskomplekser har her ofte været i søgelyset. Tit er det sket med en klar erkendelse af, at det man undersøgte var det, som foregik i hovederne på folk. Mindre har man derimod keret sig om, hvordan det er at blive set (ned) på; for slet ikke at tale om, hvordan det er at leve på og bebo de steder, som blikket rettes mod.

Tilsvarende har man ofte betonet rums og steders åbenhed. Det har været magtpåliggende at fremhæve, at steder og lokaliteter ikke er fastfrosne kasser, hvor man har levet trygt og godt - eller elendigt - i essentielle og stabile enheder. Igen og igen har man understreget, at et sted ikke er en $\varnothing$, men er indvævet andre steder med forgreninger kort eller langt ud i omverdenen (Massey 1994). Det kan dreje sig om afstanden til den næste gade eller til en by på den anden side af jordkloden - eller en tv-station. Steder er åbne, porøse og dynamisk indvævet i netværk af sociale relationer, således at steder i en vis forstand slet ikke er, udover en væren $i$ permanent flydende tilstand. Inkluderet heri har været en opfattelse af, at sted kan være et såre reaktionært begreb, der i sig rummer store muligheder for eksklusion af det Andet (Cresswell 2004: 75). Undertiden synes det, som har man i ønsket om at undkomme enhver snak om ekskluderende "roots" stirret sig blind på "routes"; ud fra den betragtning at her lavede man i hvert fald ikke noget galt.

Som en konsekvens heraf har det drejet sig om et stort og nyttigt kortlægningsarbejde af den mentale oplevelse af at være på vej, medens andre aspekter, såsom handlinger og gøremål, tilsvarende ikke har haft samme bevågenhed.

I det følgende skal der tages hul på et stykke reparationsarbejde i forhold til 
ovenstående. For det første er fokus ikke på rums og steders medialiserede repræsentationsformer, ej heller spiller blik og anskuelsesmatricer den store rolle. Snarere drejer det sig om at foretage pejlinger af, hvad det vil sige at bebo og tilegne sig et sted set indefra, dvs. hos dem der bor og lever det pågældende sted. For det andet lægges der ikke megen vægt på vejen til og fra et sted, om end det fastholdes, at et sted faktisk ikke er en ø. Det ville være dumt at skylle barnet ud med badevandet. For det tredje er det ikke den mentale side af det at bo, som er det centrale, men de handlinger og gøremål man gør brug af, når man bebor et sted.

\section{Udgangspunkter og ærinde}

Udgangspunktet for dette sidste er, at der ikke findes den handling, som ikke er allokeret og finder sted. Den finder endda sted ét sted - undertiden også flere steder, men altid lokaliseret. Et andet udgangspunkt er, at et sted ikke er, men bliver; og at det bliver til ved handling. Et tredje udgangspunkt er, at inden et sted er blevet til et sted, har det været et rum. Et rum der foreligger som en mulighed, fyldt med latent possibilisme. Det interessante er da at se nærmere på, hvorledes et rum transformeres til et sted, som altså både er unikt og absolut i sig selv og samtidig relativt og indlejret $i$ en flerhed af andre steder. Det er ærindet i denne artikel at pege på dele af en sådan kulturel transformation af et rum til et sted. Nærmere bestemt er det - med håndboldspillet som case - et formål at pege på nogle af de faktorer, der i en sammenvævning af kulturhistorie og fænomenologi indgår i en sådan transformation.

Når et boldspil som håndbold er valgt som case, sker det ud fra den betragtning, at det her i sjældent typisk grad er muligt at pege på handlingsaspektet i en stedsappropriering, og at dette kan understrege kontakten med og påvirkningen fra omverden og omgivelser. Ej heller håndboldspillet er en ø. Også idræt og sport finder sted, dvs. foregår et bestemt sted og på en bestemt lokalitet og altså ikke i et abstrakt tomrum. Sport og idræt har, sagt med andre ord, også en hidtil overset topografisk dimension, som kan være illustrativ for den kulturelle transformation fra rum til sted. Nærmere bestemt er det hensigten at vise, at det for såvel tilskuere som udøvere er et centralt element $\mathrm{i}$ idrætten at foretage en sådan transformation.

Andre illustrerende cases havde været en mulighed. Man kunne eksempelvis have undersøgt en række borgeres fysisk-kropslige bevægelsesmønstre rundt $\mathrm{i}$ byen, eller indvandrernes tilegnelse af Århus' byrum om sommeren langs strandene, eller de tyrkiske grill- og parkfester i Tiergarten i Berlin som led i en bytilegnelse og -beboelse, eller torvehandelen på Ingerslevs Plads i Århus onsdag og lørdag med både snak og indkøb, for slet ikke at nævne det at være stamkunde hos 
enten den lokale slagter eller på den lokale bodega. Eksemplerne er legio. I samtlige tilfælde ville det have været muligt at pege på handling og aktivitet som led i en tilegnelse af og en identifikationsskabelse med et sted.

For at undgå, at casen og empirien tager partikularistisk overhånd, er det samtidig et ønske at vise, at idrætten som enhver anden handling indgår i et større kulturelt kompleks, der drejer sig om, at rum, lokaliteter og steder ikke kun foreligger, men kontinuert tilegnes og bearbejdes - og at denne bearbejdelse også er af kropslig karakter. Sigtet er således ikke snævert rettet mod idrætten og idrættens rum som sådant; snarere ses idrætten som en prisme, gennem hvilken kulturelle væsenstræk lader sig belyse. Disse væsenstræk - og her sigtes især til de kulturelle transformationsprocesser - foregår aldrig i et rent mentalt rum. Tværtimod er de allokerede. De finder sted.

\section{Kulturanalysens topografiske vending}

Op gennem 1980'erne og 1990'erne foregik der inden for kulturforskningen i menneskeligt samvær i bred forstand en såkaldt kulturel vending. Den havde også karakter af at være en konstruktivistisk vending, der primært var interesseret i de betydninger, italesættelser og symbolske billeder, som blev tillagt de materielle omgivelser og den materielle kultur, og ikke materialiteten og dens væsen som sådan. Det indebar, at man ikke uden videre godtog fysiske og håndgribelige rum såsom skoven og byen og tilsyneladende "evige" historiske fænomener såsom vaner, skikke og traditioner, men så dem som socialt og historisk producerede. De blev nu dekonstrueret, dvs. analyseret som konstruktioner og opfundne traditioner, ligesom undersøgelserne af det fysiske rum blev suppleret med analyser af de drømme, længsler, forestillinger og medierede gengivelser af rummet, som knyttede sig til det fysiske aspekt. Kort sagt blev betydning betonet på bekostning af materialitet, handling og praksis. Det, der foregik i hovederne på folk, blev set som vigtigere end deres gøremål. Som det hed i et af de mest typiske konstruktivistiske værker vedrørende sammenhængen mellem rum og betydning kunne landskabet anskues som et kulturelt "image" og en billedmæssig repræsentation, som beskueren bringer med sig som led i en strukturering og en symbolisering. Et landskab er, set i denne optik, ganske vist mere håndgribeligt, men ikke mere realt end et landskabsmaleri eller et digt (Daniels og Cosgrove 1988: 1)

Imidlertid er antropologer såvel som geografer, historikere, sociologer, filosoffer begyndt at skifte perspektiv, så rumlige dimensioner nu står i forgrunden snarere end i baggrunden af analysen, hvor selve det at færdes i et rum og at tilegne sig det i stigende grad kommer i fokus. Der udvikles inden for antropologien såvel 
som andre humanistiske og samfundsvidenskabelige fag en interesse for at udføre detaljerede beskrivelser af den kulturelle praksis på specifikke steder - topoi (Kayser Nielsen 2005). Temporalitetsaspektet og tidsdimensionen suppleres af den rumlige side af vores tilværelse; det sker ud fra spørgsmål såsom: hvad vil det sige at bo og bebo? Hvilken rolle spiller kroppen i den forbindelse?

Den topografiske tilgang retter opmærksomheden mod interaktionen mellem det sociokulturelle og det kropslige i konkrete materielle rammer. Idet man opfatter det som for reduktivt at definere kultur som systemiske, symbolske og lingvistiske tildragelser (Bonnell og Hunt 1999: 26), er man i stedet begyndt at fokusere på praksis og kropslige gøremål; gøremål som er situerede. Det er her en central pointe, at gøremålenes situering ikke kun foregår i et semiotisk rum, men også på et sensorisk sted, dvs. som noget der kan erfares med begge ben på jorden ud fra en trang til at vide noget om det, som ikke uden videre kan ses og heller ikke siges. Som det i forbindelse med studier af campingpladsliv og kolonihaver lakonisk er blevet formuleret af den engelske kulturgeograf David Crouch, er det tvivlsomt, om fritidens rum kun praktiseres semiotisk (Crouch 1999: 258). Det er kropslige aktiviteter og ikke betydningsdannelse, som er det væsentlige i fritidsrummet. Centralt i denne sammenhæng bliver da spørgsmålet om, hvad rum er.

\section{Rum og sted}

Vi kan her foretage en tredelt skelnen mellem stedets lokalisering, materielle form og dets mening og værdi. Ved lokalisering forstår man, at stedet er unikt og singulært placeret i et objektivt fastlæggeligt, om end arbitrært valgt koordinatsystem med længde- og breddegrader. Det svarer til en forestilling om rummet som en slags "container", der udgør en uforanderlig i sig selv hvilende enhed. Som oftest har denne opfattelse hvilet på en rumsopfattelse, der er blevet kaldt det "absolutte rum", dvs. et to- eller tredimensionalt rum der kan bestemmes præcist ved hjælp af angivelse af positioner inden for et koordinatsystem, og som har sin absolutte og hårde afgrænsning. Af- og beskåret af grænsen som fait accompli er der entydighed og mangel på udfordring indenfor grænsens rammer.

Et sted er også materialitet. Om det nu er naturligt eller menneskeskabt eller en blanding af begge dele, er et sted altid forlenet med stoflighed. Steder er noget; de er konkrete. Selv om de kun foreligger i tanken eller fantasien udgøres de af noget. Børneværelset har fire vægge, et vindue og en dør. Selv hos Harry Potter findes der en materialitet, forstået på den måde, at også fiktive steder må fremstilles som "noget", dvs. som noget der ville have haft en materialitet, hvis det havde været ikke-fiktivt. Det er forudsætningen for, at vi kan forstå dem som andet og 
mere end streger og sorte pletter på et stykke papir. Man kan ikke tænke på et sted uden at tænke på noget (Cresswell 2004: 7). Man tænker derfor heller ikke på et sted som ingenting. Denne indsigt $\mathrm{i}$, at man tænker på noget, daterer sig tilbage til den tyske fænomenologi omkring 1900 med dens opfattelse af tanken som en intentionalitet, dvs. at tanken er en om-tanke og en på-tanke; man tænker om noget eller på noget.

For det tredje indgår der i et sted også betydning og værdi og dermed subjektive og emotionelle tilknytninger til et sted. Denne tilknytning sker i første række ved navngivning og identifikation, som er med til at gøre et sted til andet og mere end blot fysisk foreliggende som substans (Hakamies 2006). Steder produceres også gennem forestillinger og fortællinger, der er i konstant udveksling med andre fortællinger, betydninger og værdier udenfor stedet. Stedet er ikke lukket og afgrænset, men åbent for impulser udefra; det være sig af regional, national eller international art. Et sted er ganske vist singulært og unikt, men aldrig isoleret (Selberg 2007: 16).

Stedets værdi og betydning er labil og fleksibel. De fortællinger og forestillinger, der har været med til at give et sted mening, skaber oplevelser, som igen kan give anledning til nye fortællinger, fortolkninger og forestillinger. De mentale billeder, der knytter sig til steder, er underlagt løbende transformationsprocesser (Selberg 2007). Både den nævnte materialitet og den narrativt udformede værditilskrivning er altid stedt i processualitet, dvs. at steder bearbejdes (Gustafson 2002: 22, Gieryn 2000), ligesom de skabes og genskabes i kontinuerlighed. Det sker ikke kun via tankearbejde og drømmerier, men også ved handlinger og gøremål. Rummet er en kontekst for aktivitet, og det er interaktioner mellem mennesker, som udfylder rummet og stedsliggør rummet. Dette foregår i såvel en vertikal historisk som en horisontal, samtidshistorisk og -kulturel polyfoni, som understreger det dynamiske og porøse aspekt ved rummet - så meget skal Doreen Massey og de andre have - men uanset dette foregår disse åbne, løbende bearbejdninger af rummet altid et sted. Der er ingen grund til at romantisere denne polyfoni; den kan lyde ganske forfærdelig, men stedsbunden er den (Cresswell 2004: 50).

Dette har også gyldighed i idrættens verden og i sportskulturen. Også her er der tale om en topograficering, hvor man via særskilte handlinger i særskilte rum gør idrætten til andet og mere end en idé, funderet i en tab-og-vind-kode. Af afgrænsningsmæssige grunde vil vi her nøjes med at se på håndbolden og dens spillesteder. 


\section{Spillet finder sted}

De fleste boldspil vil gerne være underlagt standardiserede rammer. Af hensyn til konkurrencernes krav om lige forudsætninger er det en fordel, at de forskellige baneanlæg har samme mål, så man ved, hvad man har at holde sig til (Bale 1994: 100 ff.). Dette har imidlertid vist sig at være et næsten uopnåeligt mål. Helt ens bliver de forskellige spillesteder aldrig. Om end tendensen historisk set går i den retning, er en total kloning ikke mulig. Spillestederne har altid et vist minimum af topografisk særpræg. Partikulære forhold sætter sig altid igennem på trods af alskens ønsker om standardisering og global homogenisering. At der er en tendens til, at professionalisering fører til delokalisering, ændrer ikke ved, at selv nutidens standardiserede baner har et vist særpræg, som gør dem til "stærke" hjemmebaner - som følge af et samspil mellem tilskuerne og de fysiske rammer. Aarhus Stadion er kendt for at være et vanskeligt sted for udeholdene, medens håndboldarenaen ved siden af ikke er det. Håndboldhallerne i Gudme og Skjern er ligeledes svære at spille i for de gæstende hold.

De første af håndboldens spillesteder i byerne var hjemmehørende i kasernernes gymnastiksale, hvor der var murstensornamenter, ribber og jernstivere langs væggene, som kunne gøre det farligt at spille dér. Det var især et problem for udeholdene, som ikke var fortrolige hermed. Så småt fik man dog mere velegnede spillesteder. I Odense fik man i 1930'erne Fyns Forum at spille i, som i $1952 \mathrm{blev}$ afløst af Kostalden - navnet fik man på grund af beliggenheden ved Dyrskuepladsen i byens sydvestlige del - der med sit korkgulv af spillerne blev oplevet som nok så hyggelig og intim som baner med hårdt trægulv. Det samme gjaldt "den gamle KIF-hal" i Kolding, om end begge baner led under at have for små dimensioner til international standard, og at de var svære at spille i for udeholdene, der ikke var så fortrolige med de lokale forhold (Interview med Bjarne Andersen). De små dimensioner bevirkede, at der måtte tillempes en særlig spillestil, hvor fløjspillet ikke kunne udvikles, og hvor man i stedet måtte satse på bagspillet og store backer med tørre langskud.

Tilsvarende på landet, hvor der normalt blev spillet udendørs i sommerhalvåret. Også her havde hvert spillested sine ejendommeligheder. I Hvide Sande spillede man i begyndelsen håndbold på det areal i den sydlige del af byen, som hed Hundested som følge af de mange løsgående hunde i området, derefter på et areal i Nordhavnen tæt på indsejlingen. Sidst i 1950'erne blev spillet lagt i mere faste rammer takket være den stedlige skoleinspektør P.K. Larsen. En hal havde man ikke, men to gange om ugen trænede man i den lokale skoles gymnastiksal; ved siden af den regulære træning udendørs (Interview med Søren Juul Mikkelsen).

I landsbyen Sdr. Vilstrup i Trekantområdet var spillet som i Hvide Sande be- 
gyndt på initiativ af den lokale skolelærer, der havde fået lavet en håndboldbane bag ved skolen mellem denne og gårdejer Peter Skovs mødding. Her spillede sognets unge fodbold $\mathrm{i}$ frikvartererne, men snart tog håndbolden over. Spillet udviklede sig til andet og mere end et skolespil. Det blev henlagt til gymnastik og ungdomsforeningen. Snart var der næppe et græsstrå tilbage. Der blev trænet stort set hver aften (Interview med Henning Roed). Udendørs fejede man al modstand til side i den folkelige idræts sommerturneringer. Kulminationerne kom med sejrene i DDSG\&Is landsdækkende sommerturnering. To gange i 1960'erne blev Sdr. Vilstrup Danmarksmestre inden for den folkelige idræt. Det hørte med til historien, at hjemmebanen heller ikke her var nem at have med at gøre for udeholdene. Der var efter landsbyforhold et meget stort publikum til stede, som ikke altid udviste fair play. Det lille håndboldanlæg var en heksekedel fyldt med lige dele spænding og lokalpatriotisme.

Årsagen hertil var givetvis, at der var langt mere på spil end en tab-og-vindkode. Spillet drejede sig om Sdr. Vilstrup og om at gøre ikke kun håndboldbanens rum til et sted, men hele landsbyen. Ligesom de folkelige lege kunne bestå i at drive en træskive fra den ene landsby til den anden for herved at markere sit sted og sit territorium (Møller 1990: 115 ff.), drejede det sig også her dels om at få Sdr. Vilstrup på landkortet, dels om at bebo landsbyen. Håndboldspillet og -sejrene angik ikke kun idræt og sport, men også en såre materiel måde at bekræfte sit tilhørsforhold og sit sted at være på jord. Håndboldspillet var led i en appropriering af ens hjemsted.

Det havde ikke nødvendigvis noget med kamp, konkurrence og såkaldt usportslig optræden at gøre, som når vi i Sdr. Vilstrup hujede ad udeholdene. I Nr. Nissum tog spillerne med koner og kærester del i de sammenkomster på familien Noes gård, der fandt sted aftenen før og efter håndboldkampene (Interview med Klaus Kaae). I Hvide Sande havde håndboldspillerne i KFUM gennem flere år et tæt samarbejde med Aarhus KFUM. Ved de indsamlingskampe i Vesterhavshallen i Ringkøbing, der skulle skaffe penge til en ny hal i Hvide Sande, fik hver af Aarhus KFUM-spillerne som tak for indsatsen overrakt en røget helt, ligesom de var privat indkvarteret i Hvide Sande (Interview med Klaus Kaae; Søren Juul Mikkelsen). Håndboldspillet blev her topograficeret; det drejede sig ikke kun om penge og sejre, men også om at vise, at man var fra Hvide Sande.

Tilsvarende i Fredericia. Rivaliseringen mellem FfF og KFUM, der begyndte sidst i 1950'erne, kunne allerede omkr. 1960 samle omkring 1000 tilskuere til trods for, at holdene dengang kun spillede i kvalifikationsrækken til 3. division. Denne rivalisering fortsatte op gennem 1960'erne i takt med, at holdene rykkede op gennem 3., 2. og 1. division. Det kulminerede i første omgang sidst i 1960'erne, hvor 
begge hold kæmpede om at rykke op i 1. division. I mellemtiden var man rykket fra "Møbelhallen" og ind i den nye "Glashal". Tilskuerne indfandt sig et par timer før kampen i håb om, at få en god plads. Nogle medbragte endog trappestiger for at kunne se. 3000 tilskuere hørte til dagens orden. Til gengæld skulle spillerne så også selv lægge det mobile gulv, der i sommerhalvåret blev brugt til udstillingsvirksomhed. Arbejdet tog en uges tid, og FfF'erne og KFUM'erne hjalp hinanden. "Glashallen" blev en frygtet hjemmebane for udeholdene som følge af den intense stemning, hvor glasvæggene sørgede for at kaste lyden tilbage, så at larmen var hartad infernalsk. Der var håndboldfeber i Fredericia. Kokken fra Teaterkroen, der var FfF'-fan, kom direkte fra køkkenet. Han havde partoutkort og sad på plads med kokkehue og forklæde - efter at have hængt et skilt i vinduet: "Lukket på grund af håndbold” (Interview med Kiehn Ærensgaard). Fredericia blev Danmarks førende håndboldby. Kampen om håneretten i byen var én ting; noget andet var, at man i Glashallen kunne bekræfte sig selv i, at man var fra Fredericia, og at det var den by, man beboede og havde hjemme i. De indendørs haller, man nu spillede $i$, havde internationale og standardiserede mål og udgjorde på den måde et rum $i$ al almindelighed, men det, der foregik i disse rum, drejede sig i udpræget grad om tilegnelse af dette rum i håb om at gøre dette og ens hjemby til et sted. Man kunne også kalde det et ønske om anerkendelse.

\section{Opsamling af case}

Håndbold-casen har peget på 4 grundidéer: 1) At idræt og sport, uanset hvor meget vægt der lægges på at vinde, altid er henlagt til at finde sted i en rumlig sammenhæng, 2) At en væsentlig del af idrættens formål består i - kropsligt - at tilegne sig et bestemt rum i håb om at opnå et sådant fortrolighedsforhold hertil, at det ændrer sig fra at være et rum til at blive et sted og et hjemsted, dvs. at denne rumtilegnelse og stedliggørelse ikke kun gælder selv konkurrencens sportslige rum, dvs. baneanlægget, men det samfund - i større eller mindre skala - hvori baneanlægget befinder sig. Det være sig en landsby, en bydel, en hel by og et helt land. 3) At denne rumstilegnelse er kropsligt baseret og foregår i en permanent udveksling mellem selvforglemmelse og årvågen refleksivitet. 4) At en undersøgelse af idrætten som case kan fungere som et nøglehul, bag hvilket der åbner sig en langt større verden, som mere generelt og i almenhed handler om dels omstændighederne i og omkring transformationen fra rum til sted, dels viser, at et sted aldrig er en enklave eller en $\varnothing$, men tværtimod en lokalitet der har forbindelser ud til omverdenen, som i sin tur også virker tilbage og påvirker dette sted

Taget som case handler det om at forstå idrætten som andet og mere end blot 
"at løbe rundt efter en bold". Idræt forekommer at være et vigtigt led i en nutidig massekultur og kan med fordel analyseres som en del af en større kulturel sammenhæng, hvor det centrale er kulturelle transformationsprocesser. Det gælder for idrætskulturen som for andre kulturelle manifestationer, at folk ikke er passive "ofre" for objektive vilkår. Tværtimod synes det at være et kulturelt væsenstræk, at man konstant forholder sig bearbejdende og medproducerende i forhold til kulturen. Denne transformationsproces er kun sjældent et rent bevidsthedsanliggende. Snarere befinder man sig i en slags forhandlingssituation, hvor man både er kulturbærer og kulturskaber, dvs. man tager for sig af de til rådighed stående kulturelle tilbud og håndterer dem ud fra ønsket om at skabe sig selv og sit kulturelle tilhørsforhold. Det sker ved at investere sin krop i en løbende tilegnelse i forarbejdningsøjemed af de rammer, der står til rådighed.

Denne relation mellem at være kulturbærer og kulturskaber har berøring med spørgsmålet om identitetsdannelse, hvor man kan skelne mellem identitet som værende individuelt unik og identitet som indskrivning i en fælleshed (Fink 1991). Denne almene bestemmelse kræver imidlertid, at man ser nærmere på, hvad der indgår $\mathrm{i}$ identitetsdannelsen, forstået som en proces, der løbende finder sted. Her melder sig kropsfænomenologien med en vis aktualitet, som fx hos den amerikanske filosof Drew Leder.

\section{Identitetens kropslige dimension}

Drew Leder tager udgangspunkt i en arbejdssituation (Leder 1990: 11 ff.). Den kan ske med en høj grad af opmærksomhed på kroppens kapacitet i forhold til opgaven, hvor der foregår en bevidst afvejning af faktorer som kroppens udholdenhed og muskelstyrke. Men den kan også foregå uden en sådan opmærksomhed. Vi løser en opgave uden at tænke nærmere over den kropslige side af sagen. Når man foretager en handling, er man ikke optaget af sin krop. Det er snarere sådan, at handlingen "gennemstrømmer" ens krop. Man er mindre optaget af sin krop end af resultatet af handlingen, skriver Leder med reference til Paul Ricoeur. Leder kalder dette kroppens attentionale telos og sigter her til, at man retter sin energi bort fra ens krop, som tilsvarende henligger i en slags ikke-bemærket tilstand. Den er så at sige fraværende til stede.

Hertil knytter der sig en funktionel telos: det som kroppen kan, uden at man er sig det bevidst. Ganske vist kan man, når man går, koncentrere sig om kroppens rytme, men de fleste kropslige aspekter af det at gå er udenfor ens opmærksomhed. Hovedsagen er, at kroppen "kan". Det ville formodentlig være overordentligt vanskeligt at gøre fuldt ud rede for, hvad der foregår, når man cykler. Og i grunden 
er det også lige meget, om man har et refleksivt forhold hertil. Kroppen cykler alligevel. I begge tilfælde bruger man kroppen som det, Leder kalder "et u-tematiseret substrat" (Leder 1990: 19). Den er tavs til stede og tavst, men effektfuldt agerende.

Nedenunder disse to lag findes der imidlertid et tredje: kroppens fysiske telos. Ved de to ovenfor nævnte telos'er kunne det nemlig se ud som om, at man viljebetinget kunne vælge at suspendere opmærksomheden på kroppen, at man kunne vælge at være kroppen vár eller ej. Det er imidlertid ikke den fulde sandhed, hævder Leder. Nederst i vores kropslighed findes nemlig det uundkommelige vilkår, at dele af vores krop ikke kun er tavst til stede, men også fraværende. Fraværende i den betydning, at de ikke kan blive genstand for vores opmærksomhed. Men samtidig er dette utematiserede fravær - paradoksalt nok - det som gør, at vi er nærværende. Med et begreb, som Leder har overtaget fra Husserl, kaldes dette basale vilkår for kroppens "nulpunkt".

Denne kropslige selvforglemmelse er normalt knyttet til situationer, der er os fortrolige og velkendte, som fx når vi færdes på velkendte steder og i omgivelser, der er os selvfølgelige. Her befinder vi os i tilstande, der ikke kræver opmærksomhed. Vi smelter så at sige sammen med vores omgivelser og opgår i dem som i en helhed. Vi indgår med selvfølgelighed i rutiniserede og habituelle kontekster, der er så evidente, at vi ikke behøver at tænke nærmere over hverken os selv eller tingene omkring os. I denne selvforglemmelse kan der være inkluderet en høj grad af ro og tilpashed, der ikke kræver årvågenhed. Det er her vanskeligt at trække grænsen mellem os selv og det udenfor os. Merleau-Ponty taler i den forbindelse om, at vi her agerer med en "situationsrumlighed", hvor vores krop fremtræder som en "holdning" til en bestemt opgave (Merleau-Ponty1994: 43 f.). Det rum, vi færdes i, er her blevet til et sted, som vi uhindret gebærder os i med selvfølgelighed. Som fx når vi spiller håndbold på en os fortrolig hjemmebane, som vi har fået under huden og har et habituelt forhold til. Vi kender Kostalden ud og ind og anvender her løbebaner, der uden nærmere refleksivitet er afstemt efter forholdene, og som udføres i kropslig selvforglemsel med en attentional telos, hvor vi er opslugt af spillet og stedet. Via gøremål og uden at gøre brug af en refleksiv bearbejdelse af, hvem vi i grunden er, og hvori vores identitet består, bekræfter vi os selv $i$ at have et hjemstedsforhold til spillestedet og opnår herved en identitet, som imidlertid ikke er tematiseret, men henlagt til en kropslig selvfølgelighed. Vi hviler i os selv og opnår identitet gennem rutiniseret og vanemæssig omgang med omgivelserne. Som da græsset blev slidt ned på håndboldbanen i Sdr. Vilstrup mellem skolen og Peter Skovs mødding. Her gennemspillede man ordløst sin identitet og bekræftede sig selv i sit topografiske tilhørsforhold.

Imidlertid gennembrydes denne selvfølgelighed undertiden. Fx på udebane. 
Her har man stadig et fortroligt forhold til ens kropslige ageren som håndboldspiller. Man spiller, som man altid har gjort, attentionalt og med de velkendte angrebsmønstre og løbebaner. Og så alligevel ikke helt. Omgivelserne er ikke ens egne og er ikke mere velkendte end, at man må tænke sig om og indrette sig. Dvs. at man må træde udenfor sin normale kropslige identitet. Der opstår en vis intensitet $\mathrm{i}$ form af en spænding mellem kropsopmærksomhed og kropsforglemmelse. Man bliver opmærksom på sig selv på en anden måde end normalt.

Det tilsvarende sker, når der kommer udehold til ens egen hjemmebane. I et kort øjeblik ser man på sig selv med udeholdets briller: hvordan mon de oplever at være her? Og så forærer man Aarhus KFUM-spillerne en røget helt, dvs. en repræsentation af ens hjemstavn. Også her er der tale om en intensitet. Man erkender, at man bliver set på med udefra kommende øjne og bliver sig selv, sin krop og sit sted vár. Man gennemstrømmes af opmærksomhed og selv-bevidsthed midt i al selvforglemmelsen. Ens identitet er både en selvfølgelighed og noget, man kan erkende. Hvis man altid spillede på hjemmebane, ville denne identitetsintensiverende dobbelthed ikke være til stede. Dysten, kampen, konkurrencen eller hvad det nu kaldes, er både en tavs bekræftelse af, hvem man er, og en øjenåbner. Der er med andre ord meget mere på færde end en abstrakt tab-og-vind-kode. Denne almene kode er her knyttet til særlige omstændigheder og bliver - takket være stedsdimensionen - fra at have været et alment og generelt forehavende til et særskilt forehavende, der dialektisk forener både det almene og det specifikke. Der sker en transformation; ikke en total tilsidesættelse, men en tilførelse af en ny dimension i ens identitet. Horisonten udvides, og man beriges. Håndboldens ude- og hjemmebaner drejer sig set $\mathrm{i}$ et videre perspektiv ikke om idræt som sådan, men om kontinuerte møder med det Andet.

Disse møder finder aldrig sted ud i den blå luft, de har deres stedlige omgivelser som rammeværk. En person, som ikke har tilegnet sig og beboer et sted, vil aldrig kunne møde, men kun udfordre og true det Andet. Er vedkommende på kant med omgivelserne, er det tilsvarende svært at ikke være på kant med det Andet.

Løgstrup har spidsformuleret dette synspunkt:

Uden identifikationer med hvad vi i vor forståelse er på afstand af kan vi ikke blive os selv. Af os selv kan vi ikke blive os selv. Identificere sig med sig selv kan ingen. Identificere os kan vi kun med hvad vi er bevidste om. Uafladeligt stemte som vi er af vore omgivelser $\mathrm{i}$ deres sansbarhed er vor identitet et langt stykke deponeret i vore omgivelser. (Løgstrup 1987: 92). 
Men hermed har Løgstrup også problematiseret, at denne gensidighed udelukkende skulle være af mental art. Er samfundsmæssighed så også et spørgsmål om følelse og bevidsthed - eller er der andre dimensioner inde i billedet? Et svar på dette spørgsmål kan man i første omgang søge hos de folk, der beskæftiger sig med hverdagslivets konjunktive viden, idet man her ser en bredere forståelse af, hvad der binder folk sammen, end blot bevidsthed. Den konjunktive videns erfaringer er ikke kun af bevidsthedsmæssig art. Praksis-tilknyttede som de er, indgår der også kropslige elementer.

Som den finsk-svenske sociolog Johan Asplund har formuleret det i sine overvejelser om social responsivitet, kan denne bestå i, at den ene part fuldbyrder en adfærd, som den anden part har indledt. Dette kan fortsætte i en løbende vekselvirkning (Asplund 1987: 11). Hermed peges der på den menneskelige intersubjektivitets afhængighed af et åbent og uafsluttet mellemled - på det som sker mellem mennesker, dvs. udvekslingen mellem dem i form af sam-vær. Det er i mellemrummene mellem mennesker, mulighederne for sociabilitet befinder sig (Olsson 2003).

Set fra det receptive plan kan denne åbenhed forbindes med en medskabende afkodning, der har to vidensformer til rådighed (Mannheim 1980: 155 ff.). På den ene side står den kommunikative kundskab - meget lig Platons episteme-begreb. Den er symbolsk og refleksivt orienteret med vægten lagt på en tilstræbt éntydighed og på den kritiske distances forklaringsevne og refleksive med-viden. På den anden side står - meget lig Platons doxa-begreb - den konjunktive kundskab, der er en ikke-repræsenteret og ikke-symboliseret kommunikation, som tilhører praksisfeltet: det man gør sammen, den gensidige dybe forståelse, som man har på baggrund af en fælles forståelsesramme og et fælles erfaringsrum. Den er en slags før-forståelse, der rummer en spontan med-viden.

Den konjunktive viden er også mere intentionalt rettet mod rummet og omgivelserne, ligesom den farves af disse, således at dualismen mellem mennesket herinde og verden derude overskrides i kraft af de stemninger, der bygger bro mellem disse to sider (Høystad 1994: 69 ff.). Ifølge en sådan kulturel antropologi er mennesket ikke mindst i kraft af gøremål og handlinger kendetegnet af evnen til at åbne sig og lade sig stemme af omgivelserne, om det så er naturen, håndboldbanen eller sociale relationer. Mennesket er et ubestemt væsen, som i udgangspunktet er ufærdigt og derfor må be-stemme sig for, hvad det vil og lade sig stemme ved at indgå i håndterende og brugende omverdensrelationer (Høystad 1994: 84). 


\section{Konklusion}

Det er med andre ord relationaliteten, gensidigheden og de enkelte subjekters indflydelse på hinanden, der er det centrale. Disse gensidigheder er utænkelige uden handlinger og gøremål: smedens kat døde som bekendt af tak, og af skuebrød bliver man ikke mæt. Sådanne handlinger er udleverede til det vilkår altid at finde sted. Men samtidig er de også med til at transformere rummet til et sted. I selve denne transformation ligger der en sociabilitet indbygget. I modsætning til Doreen Masseys opfattelse af, at stedet er reaktionært, kan der i stedet være grund til at pege på, at stedet rummer mulighed for samfundsmæssighed.

\section{Litteratur}

Asplund, Johan (1987): Om hälsningsceremonier, mikromakt och asocial pratsambet. Göteborg: Korpen.

Bale, John (1994): Landscapes of Modern Sport. Leicester: Leicester University Press.

Bonnell, Victoria E. og Lynn Hunt (1999): "Introduction" i Victoria E. Bonnell og Lynn Hunt (red.): Beyond the Cultural Turn. Berkeley: University of California Press, s. 1-32.

Cresswell, Tim (2004). Place. A short introduction. Blackwell: Oxford.

Crouch, David (1999): "Intimacy and expansion of space" i David Crouch (red.): Leisure/ Tourism Geographies. Practices and Geographical Knowledge. London and New York: Routledge, s. $257-276$

Daniels, Stephen og Denis Cosgrove (1988): "Introduction: iconography and landscape" i. Denis Cosgrove og Stephen Daniels (red.): The Iconography of Landscape. University Press: Cambridge 1988, s. 1-10.

Fink, Hans 1991: Identiteters identitet, in: Hans Fink og Hans Hauge (red.): Identitet i forandring. Aarhus: Aarhus Universitetsforlag.

Gieryn, Thomas F. (2000). "A Space for Place in Sociology", Annual Review of Sociology vol. 26, nr. 1, s. 463-496.

Gustafson, Per (2002). Place, Place Attachment and Mobility. Three Sociological Studies. Göteborgs University. Department of Sociology. Göteborg Studies in Sociology No.6.

Hakamies, Pekka (2006): "Soviet Settlers on a Strange Territory: Experiences and Narratives from the Former Finnish Karelia" i Madeleine Hurd (red.): Borderland Identities. Territory and Belonging in North, Central and East Europe. Eslöv: Förlags AB Gondolin, s. 31-56.

Høystad, Ole Martin (1994): Det menneskelege og naturen. Innforing i filosofisk antropologi. Oslo: Det norske Samlaget.

Kayser Nielsen, Niels (2005). Steder i Europa. Omstridte byer, granser og regioner. Aarhus Universitetsforlag: Aarhus.

Leder, Drew (1990): The Absent Body. Chicago and London: The University of Chicago Press. Løgstrup, K.E. (1987): Solidaritet og karlighed. Essays. København: Gyldendal.

Mannheim, Karl (1980): Strukturen des Denkens. Frankfurt am Main: Suhrkamp. 
Massey, Doreen (1994): Space, Place and Gender. Minneapolis: University of Minnesota Press. Merleau-Ponty, Maurice (1994): Kroppens fanomenologi. Frederiksberg: Det lille Forlag. Møller, Jørn (1990): So i hul - og 99 andre gamle boldspil og kastelege. Gerlev: Bavnebakke.

Olsson, Gunnel (2003): Mellan Rum. En studie i fysisk och mental utveckling av kommunikation med udgångspunkt $\mathrm{i}$ en mellanstadieklass. Stockholm/Stehag: Brutus Östlings Bokförlag

Selberg, Torunn (2007): "Mennesker og steder. Innledning” i Torunn Selberg og Nils Gilje (red.): Kulturelle landskap. Sted. Fortelling og materiell kultur. Bergen: Fagbokforlaget, s. 9-20..

\section{Interview}

Klaus Kaae, Lemvig 17. 4. 2007 og 10. 5. 2007 Søren Juul Mikkelsen, Hvide Sande 17.4. 2007

Henning Roed, Fredericia 19.4. 2007

Bjarne Andersen, Morud 24. 4. 2007

Kiehn Ærensgaard, Løjt Kirkeby 25. 4. 2007 